\title{
China's emergence in East Asia under alternative trading arrangements
}

\author{
Hiro Lee ${ }^{\mathrm{a}, *}$, David Roland-Holst ${ }^{\mathrm{b}}$, Dominique van der Mensbrugghe ${ }^{\mathrm{c}}$ \\ ${ }^{a}$ Research Institute for Economics and Business Administration, Kobe University, Kobe 657-8501, Japan \\ ${ }^{\mathrm{b}}$ Department of Economics, Mills College, and Department of Agricultural and \\ Resource Economics, University of California, Berkeley, CA 94720, USA \\ ${ }^{\mathrm{c}}$ The World Bank, Washington, DC 20433, USA
}

Received 4 January 2004; received in revised form 11 May 2004; accepted 26 May 2004

\begin{abstract}
China's accelerated global emergence has changed trade patterns in the Asia-Pacific region and exerted important influence on its trilateral relationship with Japan and the United States. In this paper, we evaluate the effects of multilateral and regional trade policy scenarios that are particularly relevant to China, Japan, and the United States using a dynamic global computable general equilibrium (CGE) model. Our results suggest that the three countries would gain substantially from a trilateral free trade agreement and could realize large fractions of the residual gains from global trade liberalization. We contrast this with prospective free trade agreements (FTAs) in East Asia, and we find that these FTAs largely benefit smaller member economies (e.g., ASEAN countries).

(C) 2004 Elsevier Inc. All rights reserved.
\end{abstract}

JEL classification: F13; F15

Keywords: FTA; China; East Asia; Trilateralism; CGE model

\section{Introduction}

Over the last decade, a new landscape of economic relations has begun to emerge in the Pacific Basin. As conflicts and rivalries between the United States and Japan appear to have receded and the agenda of globalization has advanced, more countries are embracing

\footnotetext{
Corresponding author. Tel.: +81 78803 7023; fax: +81 788037059 .

E-mail addresses: hlee@rieb.kobe-u.ac.jp (H. Lee), dwrh@are.berkeley.edu (D. Roland-Holst), dvandermensbrugg@worldbank.org (D. van der Mensbrugghe).
} 
outward economic orientation and open multilateralism as a means of accelerating domestic economic growth. Most prominent of the later entrants in the regional arena is China, whose domestic economic reforms have led it to record growth rates, dramatically accelerating export expansion and sharply raising living standards. Since its entry to the WTO in December 2001, China has speeded up its domestic and external liberalization.

The emergence of China as a major trading partner has important implications for the US-Japan bilateral relationship in particular and the evolution of Asian Pacific trade patterns generally. Because of its size and stage of development, China will play two roles in the region with unusual prominence. First, it is likely to strengthen its export competitiveness in a wider range of products. Second, the size of China's growing internal market will make it the largest East Asian importer of East Asian goods. Thus China interposes itself between the rest of East Asia and the US-Japan as an export and import competitor, respectively. Asia's newly industrialized economies (NIEs) have played such a role in the past, but none are comparable to China in size or scope of potential regional influence.

Clearly, the emergence of China into this new economic prominence will be most successful if it can be accommodated into a framework of regional cooperation, particularly with respect to the most influential economies, the United States and Japan. It is not enough to simply argue that all three should get along, however, since the evolution of domestic economic conditions and external trade patterns will exert important influences on policy in all three countries. A more realistic way to promote the smooth evolution of open multilateralism in the region would be to clearly elucidate the interests and potential rewards to participating countries.

In the past decade the number of regional integration agreements (RIAs) has proliferated rapidly. Japan and Singapore signed a New-Age Economic Partnership in January 2002, Korea's National Assembly ratified Korea-Chile free trade agreement (FTA) in February 2004, and Japan and Mexico reached final accord on an FTA in March 2004. A large number of FTAs involving countries in the Asia-Pacific region are currently being negotiated, including ASEAN-China FTA, ASEAN-Japan FTA, and Japan-Korea FTA. The ASEAN+3 group, consisting of ASEAN countries, China, Japan, and Korea, has emerged primarily to provide a framework for establishing East Asian leadership and influence on regional and international affairs (Drysdale, 2002), and it has provided an effective mechanism for greater cooperation and gradual regional economic integration in East Asia. The trends in negotiating for new RIA are likely to continue.

Whether regional agreements are a facilitating intermediate step towards global free trade or a hindrance to greater global trade liberalization is a hotly debated issue (e.g., Krueger, 1999a; Laird, 1999; Panagariya, 2000). Proponents for regional integration argue that RIAs encourage member countries to liberalize beyond the level committed by multilateral negotiations and that they make tough negotiating issues easier to handle (e.g., Dutta, 2000; Kahler, 1995). In addition, RIAs are likely to induce dynamic effects that might contribute to member countries' growth through the accumulation of physical and human capital, productivity growth, and accelerated domestic reforms (e.g., Ethier, 1998; Fukase \& Winters, 2003). ${ }^{1}$ Opponents worry that the proliferation of RIAs is likely to

\footnotetext{
${ }^{1}$ Ethier (1998) suggests that small-country members are induced to lock in their liberalized trade regimes and that RIAs are congruent with further multilateral liberalization.
} 
undermine the multilateral trading system and that beneficiaries of RIAs might form a political lobby to deter further multilateral liberalization (e.g., Bhagwati, 1995; Levy, 1997; Panagariya, 1999; Srinivasan, 1998a, 1998b).

Empirical evidence on benefits and costs of RIAs suggests that trade creation exceeds trade diversion in almost all RIAs (Robinson \& Thierfelder, 1999). The positive effect on economic welfare resulting from the European Union (EU) and North American Free Trade Agreement (NAFTA) is supported by Brown, Deardorff, and Stern (1992), Harrison, Rutherford, and Tarr (1996), Lee and van der Mensbrugghe (2004), and Roland-Holst, Reinert, and Shiels (1992). However, Yeats (1998) finds that during 1988-1994 Mercosur countries experienced significant trade diversion when their intra-Mercosur trade increased sharply.

Using a dynamic global computable general equilibrium (CGE) model, we evaluate the effects of prospective free trade agreements involving East Asian countries, including China-Japan-US FTA. In addition, we examine the effects of China's unilateral trade liberalization and global trade liberalization. Section 2 gives an overview of the model. Section 3 provides a brief description of scenarios and assessments of computational results. Section 4 summarizes the main policy conclusions.

\section{Overview of the model}

The model used in this study, known as the LinKAGE model, is a dynamic global CGE model developed by van der Mensbrugghe (2003). ${ }^{2}$ It spans the period 1997-2015 and is a relatively standard neoclassical CGE, with constant returns to scale in all sectors, perfect competition and price-clearing behavior in all markets. The model incorporates three types of production structure-crops, livestock, and manufacturing and services. The first distinguishes intensive (chemical- and labor-based) farming versus extensive (land-based) farming. Livestock production is characterized by ranch-fed versus range-fed cattle. All other sectors conform to the more standard labor-capital substitution effects, albeit with sufficient structure to capture the complex interactions across various inputs and factors of production (see Fig. 1). ${ }^{3}$

Factor income accrues to a single representative household, which finances government expenditures (through direct and indirect taxes) and investment (through domestic savings). Domestic savings may be augmented or diminished by a net capital flow. In the current version of the model, the latter is exogenous in any given time period for each region, thereby generating a fixed current account balance. Ex ante shocks to the current account-e.g., a reduction in trade barriers-induces a change in the real exchange rate. Government fiscal balances are also fixed in each time period, and the equilibrating

\footnotetext{
${ }^{2}$ See van der Mensbrugghe (2003) for the model equations. To some extent, this section replicates Lee and van der Mensbrugghe (2004) (Section 2).

3 At the top nest, production is formed by the combination of aggregate intermediate demand other than energy (ND) and value added plus energy (VA). The second nest consists of two nodes. The first node decomposes aggregate intermediate demand into sectoral demand for goods and services. The second node decomposes VA between demand for aggregate labor $(L)$ and demand for human capital, physical capital, energy, and sector-specific factor bundle (HKTE). The third and subsequent nodes are decomposed by a similar fashion, as illustrated in Fig. 1.
} 


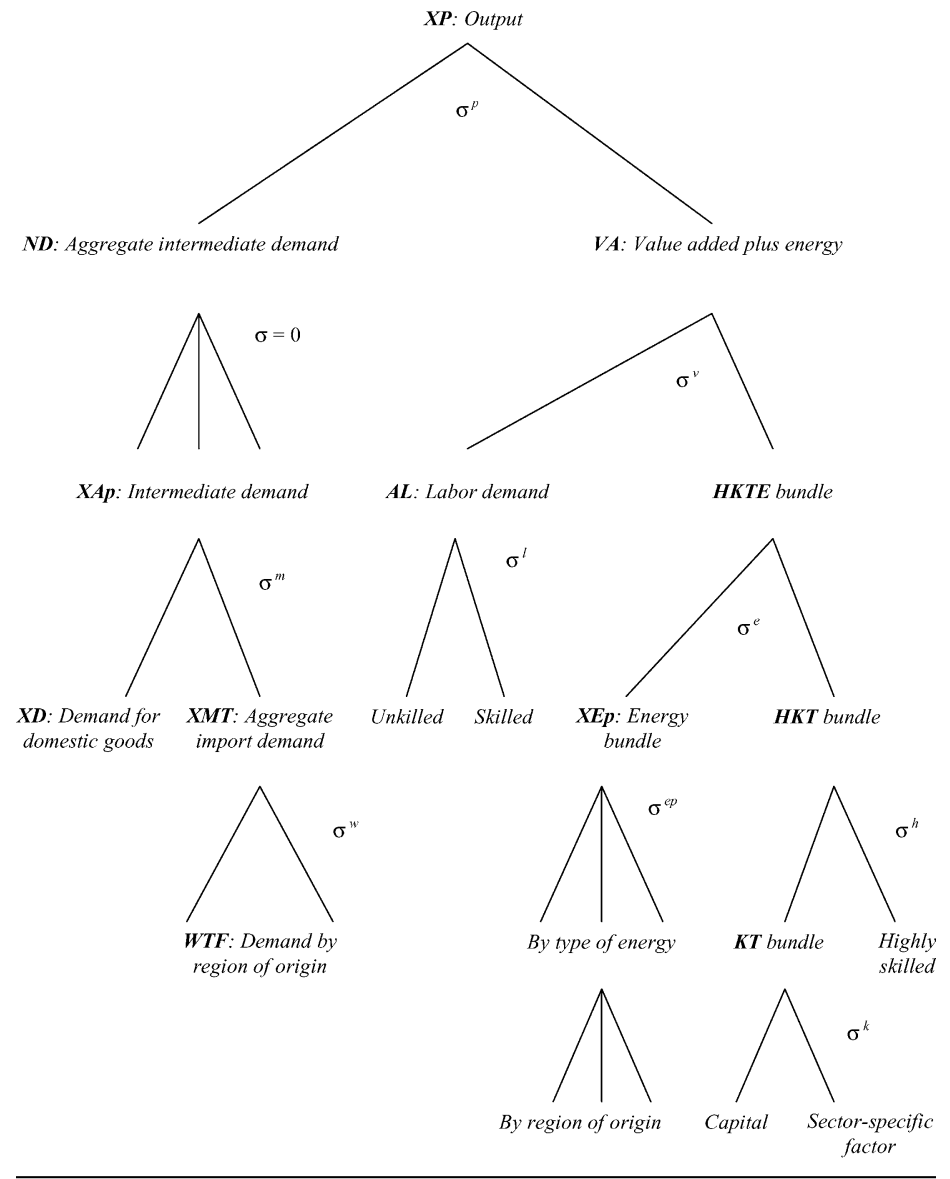
Definition of variables and parameters:
ND: $\quad$ Demand for aggregate non-energy intermediate demand
$V A$ : Demand for labor, capital, energy, and sector-specific factor bundle
$X A p: \quad$ Demand for (Armington) intermediate goods (excluding energy)
$X D: \quad$ Demand for domestically produced intermediate goods
XMT: $\quad$ Aggregate import demand for intermediate goods
WTF: Demand for imported intermediate goods by region of origin
$A L: \quad$ Demand for aggregate labor (excluding highly skilled)
HKTE: Demand for human and physical capital, energy, and sector-specific factor bundle
$X E p: \quad$ Demand for aggregate energy bundle
$H K T$ : Demand for human capital, physical capital, and sector-specific factor bundle
$K T: \quad$ Demand for physical capital and sector-specific factor bundle
$\sigma^{p}: \quad$ Elasticity of substitution between $N D$ and $V A$
$\sigma^{v}: \quad$ Elasticity of substitution between $A L$ and $H K T E$
$\sigma^{l}: \quad \quad$ Elasticity of substitution between unskilled and skilled labor
$\sigma^{e}: \quad$ Elasticity of substitution between $X E p$ and $H K T$
$\sigma^{e p}: \quad \quad$ Elasticity of substitution between different type of energy
$\sigma^{h}: \quad$ Elasticity of substitution between $K T$ and highly skilled labor
$\sigma^{k}$ : $\quad$ Elasticity of substitution between physical capital and sector-specific factor

Note: The sector-specific factor includes land in agricultural sectors and the resource base in the coal, crude oil, natural gas, and mining sectors.

Fig. 1. Production nesting in the manufacturing and services sectors. 
mechanism is lump-sum taxes on the representative household. For example, a reduction in tariff revenue is compensated by an increase in household direct taxation.

Trade is modeled using the ubiquitous Armington assumption of imperfect substitution, i.e., goods are differentiated by region of origin. The model uses a nested demand structure. Aggregate domestic absorption by sector is allocated between domestic goods and a single composite import good. The latter is then allocated across region of origin to determine the bilateral trade flows on a sectoral basis. An analogous dual-nested structure is used to allocate domestic production between domestic and export markets (using constant elasticity of transformation functions).

The model has four trade prices incorporating four separate instruments. First, producers receive price PE for exported goods. Second, the FOB price, WPE, includes domestic export taxes or subsidies. Third, the CIF price, WPM, includes the direct costs of port-toport shipping, represented by the ad valorem wedge $\zeta$, as well as a non-monetary or frictional cost, ${ }^{4}$ represented by the iceberg parameter $\lambda .{ }^{5}$ Thus the relationship between the FOB price and the CIF price is given by:

$$
\mathrm{WPM}_{r, r^{\prime}, i}=\left(1+\zeta_{r, r^{\prime}, i}\right) \frac{\mathrm{WPE}_{r, r^{\prime}, i}}{\lambda_{r, r^{\prime}, i}}
$$

where subscripts $r, r^{\prime}$, and $i$ denote exporting region/country, importing region/country, and commodity, respectively. Finally, the domestic price of imports, PM, is equal to the CIF price, WPM, plus the ad valorem tariff (or tariff-equivalent) rate.

Dynamics in this model is recursive. Population and labor supply growth are exogenous. Land and (sector-specific) natural resources supply curves are price-sensitive within period, but land is only partially mobile across agricultural sectors. Capital accumulation is based on past savings and investment. The model incorporates a vintage structure for capital that allows for adjustment costs. New capital is assumed to be perfectly mobile across sectors, whereas installed capital is only partially mobile. All else equal, countries with higher savings rates will have more 'flexible' capital since it is assumed that substitution elasticities are higher with new capital than with installed capital.

The final important ingredient in the dynamic behavior of the model regards the productivity assumptions. Agricultural productivity is given in the baseline. Productivity in manufacturing and services is calibrated in order to achieve some target for real per capita GDP growth. ${ }^{6}$ In these sectors, productivity is the sum of three components. There is a sector-specific component, a component linked to the sectoral export-output ratio (the 'openness' component), and an economywide component. The latter is the calibration component (i.e., one target-one instrument). The sector-specific component is based on an aggregate assumption, typically that productivity is some percentage point higher in manufacturing than in services (e.g., $2 \%$ points). The openness component is calibrated in

\footnotetext{
${ }^{4}$ This type of cost is referred to as 'iceberg' transport cost, developed by Samuelson (1952) based on a concept developed earlier by von Thünen. More recently, these have been used in work by Helpman and Krugman (1985) and Fujita, Krugman, and Venables (1999).

5 A rise in $\lambda$ represents an improvement in trade 'efficiency' and thus a reduction in trade cost. This could correspond to a reduction in administrative barriers to trade (e.g., customs procedures) and/or a lower technical barrier (e.g., mutual recognition of technical standards in production, packaging and marketing).

${ }^{6}$ Productivity is assumed to be labor-augmenting.
} 
the baseline so that it explains a specified share of total sectoral productivity. In policy reforms scenario, this component $\left(\chi_{i, t}\right)$ is assumed to be endogenous, i.e., it changes with the ratio of exports to output:

$$
\chi_{i, t}=\phi_{i, t}\left(\frac{E_{i, t}}{X_{i, t}}\right)^{\eta_{i}}
$$

where $E_{i, t}$ is exports of commodity $i, X_{i, t}$ is output of commodity $i, \phi_{i, t}$ is a shift parameter, and $\eta_{i}$ is the elasticity of productivity with respect to openness. For example, if manufacturing productivity in the baseline is $4 \%$ in some year, the openness component explains $50 \%$ of total sectoral productivity, and the export-output ratio increases by $10 \%$, then productivity would increase by $5 \%$ (to $4.2 \%$ ) assuming the openness elasticity is one. ${ }^{7}$

Previous studies have shown that two additional factors that are not incorporated in the present model would significantly boost the gains from trade. First, Brown and Stern (1989), Francois and Roland-Holst (1997), and Harris (1984), among others, have demonstrated that incorporation of increasing returns to scale and imperfect competition could lead to multiple changes in the aggregate results. Second, foreign capital flows (e.g., foreign direct investment and portfolio investment) are exogenous in the current version of the model, but it has been shown that allowing for capital to flow to countries with relatively high rates of return could significantly raise the gains from trade reform. ${ }^{8}$

Most of the data used in the model come from the GTAP database, version 5.2, which provides 1997 data on input-output, value added, final demand, bilateral trade, tax and subsidy data for 76 regions and 57 sectors. ${ }^{9}$ For the purpose of the present study, the database is aggregated into 9 regions and 18 sectors. ${ }^{10}$

\section{Scenarios and results}

\subsection{Policy scenarios}

To evaluate prospective free trade agreements in the wake of China's emergence, the following seven policy scenarios are considered:

(1) China's unilateral trade liberalization

\footnotetext{
${ }^{7}$ Note that if the export-output ratio increases by $10 \%$, then assuming $\eta_{i}=1$ the openness component of productivity, $\chi_{i, t}$ increases by $10 \%$. Since the other two components of productivity are exogenous, an increase in sectoral productivity is calculated as $\left[\theta_{\chi}\left(1+g_{\chi}\right)+\left(1-\theta_{\chi}\right)\right]-1=[0.5(1+0.10)+(1-0.5)]-1=0.05$, where $\theta_{\chi}$ is the share of sectoral productivity explained by the openness component and $g_{\chi}$ is the rate at which $\chi_{i, t}$ increases.

${ }^{8}$ See, for example, Petri (1997) and Lee and van der Mensbrugghe (2001).

9 Dimaranan and McDougall (2002) give detailed descriptions of the GTAP database, version 5.0. The number of regions is increased from 66 to 76 in version 5.2, which disaggregates the Central and Eastern European regions into single countries.

${ }^{10}$ The 9 regions are (1) China and Hong Kong, (2) Japan, (3) Korea, (4) Taiwan, (5) ASEAN, (6) United States, (7) Canada, Australia, and New Zealand, (8) EU-15, and (9) the rest of the world. The 18 sectors are (1) rice, (2) other grains, (3) oil seeds, (4) sugar, (5) other crops, (6) livestock, (7) energy, (8) processed food, (9) textiles, (10) wearing apparel, (11) leather, (12) basic manufactures, (13) motor vehicles, (14) other transportation equipment, (15) electronic equipment, (16) other manufactures, (17) construction, and (18) services.
} 
(2) ASEAN-China FTA: Free trade among the ASEAN countries and China/Hong Kong

(3) ASEAN-Japan FTA: Free trade among the ASEAN countries and Japan

(4) ASEAN+3: Free trade among the ASEAN countries, China/Hong Kong, Japan, and Korea

(5) ASEAN-China-EU: Free trade among the three regions

(6) China-Japan-US FTA: Trilateral trade liberalization among the emergent Pacific economies

(7) Global trade liberalization (GTL): Complete abolition of import tariffs and export subsidies

While the likelihood of actually completing the above trade liberalization or FTAs within a reasonable time horizon differs significantly across scenarios, it is worth examining each of them. Scenario 1 is plausible because China is in the process of unilaterally reducing its tariff rates and Chinese growth in part is being led by trade. Scenario 2 is expected to be realized as ASEAN countries and China signed a framework agreement in 2002 to establish an FTA within 10 years. Scenario 3 that excludes sensitive sectors has also become a real possibility after ASEAN and Japan signed an agreement on the Comprehensive Economic Partnership (CEP) in November 2003. ${ }^{11}$ Although negotiations for an FTA among the economies of ASEAN+3 have not yet begun, we include scenario 4 because a number of studies have examined the possible effects of such an arrangement (e.g., Brown, Deardorff, \& Stern, 2003; Tran, 2003). In addition, as the EU is becoming more conscious of the role of China in the global economy and its potential implications, it is unlikely to remain idle. Given that it has established a cooperative relationship with ASEAN, it would be natural to consider scenario 5 in which ASEAN, China, and the EU form an FTA. The China-Japan-US FTA scenario is considered because China is expected to gain a great deal if it can establish an FTA with its two largest trading partners. Finally, we have the global trade liberalization (GTL) or full WTO scenario so that the effects of the unilateral and regional scenarios may be discussed relative to the global scenario.

As observed in a number of recent FTA negotiations, some countries and regions, Japan and the EU in particular, are likely to resist liberalizing their agricultural markets. Given the continued political sensitivities associated with agricultural protection, we also run alternative versions of scenarios 2-6 in which trade barriers on agricultural products and processed food remain fixed. Altogether, we conduct 12 experiments. It should be noted that in reality trade barriers on agricultural products are lowered to some extent in many FTAs. Thus, the results of the scenarios with no reductions in trade barriers on agricultural products are likely to provide the lower bound of welfare changes.

In all 12 experiments, we gradually remove bilateral tariffs and export subsidies of the relevant sectors among the member countries over the $2005-2010$ period. We set the elasticity of productivity with respect to openness, $\eta_{i}$, to 0.75 in agricultural sectors and to 1.0 in all other sectors. We assume that non-monetary trade costs would be reduced by $2 \%$

\footnotetext{
$\overline{11}$ Yamazawa and Hiratsuka (2003) provides an overview of ASEAN-Japan Comprehensive Economic Partnership.
} 
in all FTA scenarios, but they remain unchanged in the unilateral and global scenarios (scenarios 1 and 7). ${ }^{12}$

\subsection{Effects on Welfare}

Aggregate income gains and/or losses summarize the extent trade distortions are hindering growth prospects and the ability of economies to use the gains to help those whose income could potentially decline. We compared the four counterfactual scenarios with the baseline situation in the terminal year, 2015, using Hicksian equivalent variation $(\mathrm{EV})$ as the welfare measure. This represents the income consumers would be willing to forego to achieve post-reform well-being $\left(u^{\mathrm{p}}\right)$ compared to baseline well-being $\left(u^{\mathrm{b}}\right)$ at baseline prices $\left(p^{\mathrm{b}}\right)$ :

$$
\mathrm{EV}=E\left(P^{\mathrm{b}}, u^{\mathrm{p}}\right)-E\left(p^{\mathrm{b}}, u^{\mathrm{b}}\right)
$$

where $E$ represents the expenditure function to achieve utility level $u$ given a vector of prices $p$ (superscript $b$ represents baseline levels, and $\mathrm{p}$ the post-reform levels). The model uses the extended linear expenditure system (ELES), which incorporates savings in the consumer's utility function (Howe, 1975; Lluch, 1973). The ELES expenditure function is easy to evaluate at each point in time.

Table 1 summarizes the welfare results for the seven policy scenarios as deviations in EVs from the baseline in 2015. The GTL or full WTO scenario is the most attractive for almost all countries and regions. To be realistic, however, the WTO process is fraught with uncertainty about the scope, depth, and timeliness of multilateral commitments to abolish trade barriers. ${ }^{13}$ This kind of uncertainty has been an important impetus to regional agreements, particularly those between small groups of nations who find consensus, implementation, and monitoring easier.

When China removes its trade barriers unilaterally (scenario 1), its economic welfare is predicted to increase by $\$ 73$ billion $(2.9 \%)$ in 2015 , or by more than a half of the gains it can accrue from the GTL. All the trading partners also benefit, and the gains to Taiwan, Korea, and ASEAN countries are relatively large in percentage terms. These results suggest that Chinese trade policy is not only important for the future growth of China but for the future performance of East Asian trading partners.

In the ASEAN-China FTA scenario (scenario 2), in 2015 EV of ASEAN increases by $2.5 \%$, whereas EV of China increases by a smaller percentage (1.4\%). This largely results from two factors: (1) the share of ASEAN's exports to China is significantly larger than the share of China's exports to ASEAN; (2) the exports to output ratio is substantially higher for ASEAN countries. The welfare effects on non-member countries are extremely small. When ASEAN and Japan form an FTA (scenario 3), ASEAN's EV increases by $2.7 \%$,

\footnotetext{
12 Smith and Venables (1988) use a 2.5\% reduction in intra-EU trade costs in their study of the Single Market program's possible pro-competitive effects, whereas Keuschnigg and Kohler (2000) and Madsen and Sorensen (2002) use a 5\% reduction in real costs of trade between the EU and Central and East European countries. We use a smaller reduction in these costs among the members of FTAs in scenarios 2-6 because the reductions in technical barriers are expected to be smaller in these cases than in the EU case.

${ }^{13}$ For example, the Fifth WTO Ministerial Conference in Cancún in September 2003 ended with no concrete agreement for the future course of the negotiations.
} 
Table 1

Effects on welfare (deviations in equivalent variations from the baseline in 2015)

\begin{tabular}{|c|c|c|c|c|c|c|c|}
\hline \multirow[t]{2}{*}{ Region } & \multicolumn{7}{|l|}{ Senarios $^{\mathrm{a}}$} \\
\hline & $\begin{array}{l}\text { (1) China } \\
\text { unilateral }\end{array}$ & $\begin{array}{l}\text { (2) ASEAN- } \\
\text { China }\end{array}$ & $\begin{array}{l}\text { (3) ASEAN- } \\
\text { Japan }\end{array}$ & $\begin{array}{l}\text { (4) ASEAN } \\
+3\end{array}$ & $\begin{array}{l}\text { (5) ASEAN- } \\
\text { China-EU }\end{array}$ & $\begin{array}{l}\text { (6) China- } \\
\text { Japan-US }\end{array}$ & $\begin{array}{l}\text { (7) } \\
\text { GTL }\end{array}$ \\
\hline \multicolumn{8}{|c|}{ (A) Absolute deviations (US\$ billion in 1997 prices) } \\
\hline China and Hong Kong & 73.3 & $34.8^{1}$ & -3.0 & 102.3 & 74.1 & 105.3 & 134.8 \\
\hline Japan & 13.5 & 1.4 & 18.2 & 66.3 & 4.8 & 77.3 & 116.1 \\
\hline Korea & 5.0 & -0.4 & 1.2 & 30.1 & -1.9 & -4.3 & 29.1 \\
\hline Taiwan & 5.6 & -1.5 & -0.7 & -5.4 & -2.8 & -5.5 & 12.7 \\
\hline ASEAN $^{\mathrm{b}}$ & 5.4 & 26.0 & 28.4 & 41.8 & 43.0 & -16.5 & 38.1 \\
\hline United States & 13.8 & 0.8 & -1.4 & -0.9 & -2.9 & 60.6 & 70.9 \\
\hline Canada and $\mathrm{ANZ}^{\mathrm{c}}$ & 1.2 & 0.2 & -0.4 & -0.2 & -0.6 & -2.9 & 17.3 \\
\hline EU-15 & 16.9 & 3.9 & 0.2 & 6.8 & 127.9 & -0.3 & 165.9 \\
\hline Rest of the world & 7.9 & -3.6 & -2.4 & -9.8 & -18.4 & 15.5 & 147.4 \\
\hline World & 142.4 & 61.8 & 37.7 & 231.1 & 223.4 & 198.1 & 732.2 \\
\hline \multicolumn{8}{|l|}{ (B) Percentage deviations } \\
\hline China and Hong Kosng & 2.9 & 1.4 & -0.1 & 4.0 & 2.9 & 4.1 & 5.3 \\
\hline Japan & 0.3 & 0.0 & 0.4 & 1.6 & 0.1 & 1.9 & 2.8 \\
\hline Korea & 0.6 & -0.1 & -0.1 & 3.7 & -0.2 & -0.5 & 3.6 \\
\hline Taiwan & 1.0 & -0.3 & -0.1 & -1.0 & -0.5 & -1.0 & 2.4 \\
\hline ASEAN & 0.5 & 2.5 & 2.7 & 4.0 & 4.2 & -1.6 & 3.7 \\
\hline United States & 0.1 & 0.0 & 0.0 & 0.0 & 0.0 & 0.6 & 0.7 \\
\hline Canada and ANZ & 0.1 & 0.0 & 0.0 & 0.0 & 0.0 & -0.2 & 1.4 \\
\hline EU-15 & 0.2 & 0.0 & 0.0 & 0.1 & 1.5 & 0.0 & 2.0 \\
\hline Rest of the world & 0.1 & -0.1 & 0.0 & -0.2 & -0.3 & -0.3 & 2.4 \\
\hline World & 0.4 & 0.2 & 0.1 & 0.7 & 0.6 & 0.6 & 2.1 \\
\hline
\end{tabular}

a Scenarios: (1) China's unilateral trade liberalization; (2) ASEAN-China FTA; (3) ASEAN-Japan FTA; (4) ASEAN+3 FTA: free trade among ASEAN, Japan, China/Hong Kong, and Korea; (5) ASEAN-China-EU: free trade among the three regions; (6) China-Japan-US FTA; (7) global trade liberalization.

${ }^{\mathrm{b}}$ Only Indonesia, Malaysia, the Philippines, Singapore, Thailand, and Vietnam are included in ASEAN. In the GTAP database, Brunei, Cambodia, Laos, and Myanmar are aggregated into the rest of the world.

${ }^{\mathrm{c}}$ Canada, Australia, and New Zealand.

whereas the increase in Japan's EV is relatively small. Welfare of other East Asian countries (China, Korea, and Taiwan) declines slightly.

Under the ASEAN+3 FTA scenario (scenario 4), the welfare of all members increases. ${ }^{14}$ ASEAN and Korea are expected to accrue greater welfare gains under this scenario than under the GTL primarily because they will have preferential accesses to the Chinese and Japanese markets. In particular, their exports to China increase dramatically as China is predicted to become East Asia's largest importing country by 2005. China's welfare is expected to increase by $4.0 \%$ compared with a $5.3 \%$ gain under the GTL.

If free trade among ASEAN, China, and the EU is realized (scenario 5), ASEAN is expected to capture even greater gains $(4.2 \%)$ than under the ASEAN+3 FTA. EVs of China and the EU is predicted to increase by $2.9 \%$ and $1.5 \%$, respectively.

The United States would clearly prefer global liberalization to any of the regional arrangements under consideration, but the China-Japan-US FTA (scenario 6) could be a very attractive stepping stone to globalization. In this scenario, about $85 \%$ of the GTL's

\footnotetext{
${ }^{14}$ When productivity does not depend upon trade, China's welfare is virtually unchanged because the deterioration in its terms of trade offsets real output gains (Lee, Roland-Holst, \& van der Mensbrugghe, 2002).
} 
Table 2

Effects on welfare when trade barriers on food and agricultural products remain fixed (deviations in equivalent variations from the baseline in 2015)

\begin{tabular}{|c|c|c|c|c|c|}
\hline \multirow[t]{2}{*}{ Region } & \multicolumn{5}{|l|}{ Senarios } \\
\hline & $\begin{array}{l}\text { (8) ASEAN- } \\
\text { China }\end{array}$ & $\begin{array}{l}\text { (9) ASEAN- } \\
\text { Japan }\end{array}$ & $\begin{array}{l}\text { (10) ASEAN } \\
+3\end{array}$ & $\begin{array}{l}\text { (11) ASEAN- } \\
\text { CHINA-EU }\end{array}$ & $\begin{array}{l}\text { (12) China- } \\
\text { Japan-US }\end{array}$ \\
\hline \multicolumn{6}{|c|}{ (A) Absolute deviations (US\$ billion in 1997 prices) } \\
\hline China and Hong Kong & 21.5 & -1.2 & 45.8 & 44.7 & 62.9 \\
\hline Japan & 2.3 & 4.7 & 28.7 & 6.6 & 35.8 \\
\hline Korea & -0.5 & -0.7 & 12.4 & -1.6 & -2.9 \\
\hline Taiwan & -1.4 & -0.6 & -5.2 & -2.7 & -5.1 \\
\hline ASEAN & 17.2 & 12.3 & 25.9 & 27.4 & -14.5 \\
\hline United States & 0.7 & -0.4 & 1.0 & -2.7 & 45.4 \\
\hline Canada and ANZ & 0.3 & -0.1 & 0.2 & -0.4 & -1.8 \\
\hline EU-15 & 3.4 & 0.3 & 6.8 & 105.9 & -0.2 \\
\hline Rest of the world & -1.9 & -1.1 & -4.4 & -14.7 & -9.4 \\
\hline World & 41.6 & 13.1 & 111.2 & 162.5 & 110.2 \\
\hline \multicolumn{6}{|l|}{ (B) Percentage deviations } \\
\hline China and Hong Kong & 0.9 & -0.1 & 1.9 & 1.8 & 2.6 \\
\hline Japan & 0.1 & 0.1 & 0.7 & 0.2 & 0.9 \\
\hline Korea & -0.1 & -0.1 & 1.5 & -0.2 & -0.4 \\
\hline Taiwan & -0.3 & -0.1 & -1.0 & -0.5 & -1.0 \\
\hline ASEAN & 1.7 & 1.2 & 2.6 & 2.7 & -1.4 \\
\hline United States & 0.0 & 0.0 & 0.0 & 0.0 & 0.5 \\
\hline Canada and ANZ & 0.0 & 0.0 & 0.0 & 0.0 & -0.1 \\
\hline EU-15 & 0.0 & 0.0 & 0.1 & 1.3 & 0.0 \\
\hline Rest of the world & 0.0 & 0.0 & -0.1 & -0.2 & -0.2 \\
\hline World & 0.1 & 0.0 & 0.3 & 0.5 & 0.3 \\
\hline
\end{tabular}

Scenarios (8)-(12) are same as scenarios (2)-(6), respectively, except that trade barriers on food and agricultural products remain fixed.

benefits would be obtained in exchange for liberalizing only two components of US bilateral trade. The arrangement would also be incentive compatible for the other two countries. China enjoys about $78 \%$ of the GTL's benefits under the trilateral FTA, whereas Japan obtains two-thirds of the benefits. For these three countries, China-Japan-US FTA dominates the other FTA scenarios.

Table 2 provides the welfare results for the five FTA scenarios when trade barriers on food and agricultural products remain fixed. In the absence of agricultural liberalization, welfare gains to the member countries of prospective FTAs become significantly smaller. For example, Japan's welfare gains from the ASEAN-Japan, ASEAN+3, and ChinaJapan-US FTAs would be reduced by $54-74 \%$ when agricultural and food products are excluded from the agreements. China's gains from the ASEAN-China, ASEAN+3, ASEAN-China-EU, and China-Japan-US FTAs would be reduced by $38-55 \%$. By not liberalizing agricultural trade among the member countries, a very large proportion of distortions remain, particularly in trade with Japan and the EU. In this case, economic incentives to form FTAs are greatly lessened. Because strong resistances to agricultural liberalization are likely to persist in most of the prospective FTAs considered in this study, only small concessions are expected. 
Table 3

World trade matrix in the baseline, 2015 (US\$ billion in 1997 prices)

\begin{tabular}{|c|c|c|c|c|c|c|c|c|c|c|}
\hline \multirow[t]{2}{*}{ Exporting region } & \multicolumn{10}{|c|}{ Importing region } \\
\hline & $\begin{array}{l}\text { China } \\
\text { and HK }\end{array}$ & Japan & Korea & Taiwan & ASEAN & $\begin{array}{l}\text { United } \\
\text { States }\end{array}$ & $\begin{array}{l}\text { Canada } \\
\text { and ANZ }\end{array}$ & EU-15 & ROW & World \\
\hline China/Hong Kong & 49.1 & 106.5 & 32.3 & 22.2 & 66.8 & 209.3 & 28.8 & 182.4 & 129.1 & 826.4 \\
\hline Japan & 123.9 & & 46.5 & 51.5 & 112.7 & 192.4 & 29.6 & 142.6 & 89.1 & 788.4 \\
\hline Korea & 74.4 & 25.2 & & 11.1 & 42.2 & 46.4 & 10.6 & 49.3 & 64.4 & 323.8 \\
\hline Taiwan & 86.3 & 19.4 & 5.2 & & 31.1 & 58.1 & 8.5 & 42.1 & 17.4 & 268.2 \\
\hline ASEAN & 96.8 & 77.0 & 24.9 & 32.0 & 164.4 & 144.1 & 28.5 & 164.8 & 91.3 & 823.8 \\
\hline United States & 107.1 & 149.8 & 70.8 & 53.3 & 121.5 & & 281.1 & 435.6 & 414.2 & $1,633.3$ \\
\hline Canada and ANZ & 31.5 & 40.5 & 20.8 & 10.5 & 27.1 & 305.9 & 16.9 & 68.4 & 46.9 & 568.6 \\
\hline EU-15 & 108.5 & 160.6 & 65.9 & 39.7 & 152.4 & 392.8 & 100.3 & $2,177.2$ & 713.4 & $3,910.9$ \\
\hline Rest of world & 91.9 & 117.0 & 62.0 & 17.0 & 101.2 & 415.4 & 43.4 & 631.0 & 514.3 & $1,993.2$ \\
\hline World & 769.6 & 696.0 & 328.5 & 237.3 & 819.5 & $1,764.5$ & 547.8 & $3,893.3$ & $2,080.1$ & $11,136.6$ \\
\hline
\end{tabular}

\subsection{Effects on bilateral and world trade flows}

Before examining the effects of selected regional arrangements on trade flows, we first present the world trade matrix in the baseline for the year 2015 in Table 3. We observe a number of large asymmetries in bilateral trade. For example, China's exports to other East Asian economies (Japan, Korea, Taiwan, and ASEAN) are significantly smaller than its imports from these economies, whereas its exports to the United States and the EU are almost double its imports from these regions. By contrast, Japan runs large trade surpluses with other East Asian economies. This might create greater incentives for the rest of East Asia to form an FTA with China than with Japan, particularly if the Japanese government is reluctant to open its agricultural market. For China and Japan, the United States is a very important trading partner as both countries send about one-quarter of their exports to the largest country in the world.

Tables 4 and 5 present world trade flow adjustments resulting from free trade among the ASEAN+3 countries and China-Japan-US FTA, respectively. Figures are given in deviations from the baseline scenario in 2015 in billions of 1997 US dollars. These tables provide the extent of trade creation and trade diversion at the aggregate level. ${ }^{15}$ Under the ASEAN+3 FTA, China would suffer relatively large import diversion because the large increases in imports from the member countries results in reductions in imports from the non-member countries/regions. The extent of import diversion is much smaller for Japan, Korea, and ASEAN, but these countries would experience relatively large export diversion, shown by significant reductions in their exports to the non-member countries/regions.

The trade flow tables need closer inspection, particularly to obtain deeper insights about bilateral interactions and incentive properties. China's significant trade surplus with the

\footnotetext{
${ }^{15}$ We intend to examine trade creation and trade diversion at the commodity level in the future. Krueger (1999b) suggests that if reductions in imports from non-member countries are associated with increases in imports from the member countries, there would be a strong presumption of trade diversion. Alternatively, as suggested by Kreinin and Plummer (1994), one could compute indices of revealed comparative advantage (RCA) and correlate RCA rankings of commodities with various FTA scenarios and those with the GTL scenario to examine how "natural" the groupings would be.
} 
Table 4

Effects on trade flows resulting from free trade among ASEAN+3 countries (deviations from the baseline in 2015 in US\$ billion in 1997 prices)

\begin{tabular}{lrrrrrrrrrr}
\hline Exporting region & \multicolumn{1}{l}{ Importing region } & & & & & & & \\
& \multicolumn{1}{l}{$\begin{array}{l}\text { China } \\
\text { and HK }\end{array}$} & Japan & Korea & Taiwan & ASEAN & $\begin{array}{l}\text { United } \\
\text { States }\end{array}$ & $\begin{array}{l}\text { Canada } \\
\text { and ANZ }\end{array}$ & EU-15 & ROW & World \\
& & & & & & & & & \\
\hline China/Hong Kong & 33.5 & 60.7 & 40.6 & 0.7 & 49.9 & 10.9 & 1.5 & 12.0 & 5.0 & 214.8 \\
Japan & 118.6 & & 28.8 & -7.2 & 44.2 & -31.5 & -4.6 & -19.8 & -11.5 & 117.1 \\
Korea & 66.7 & 28.0 & & -2.2 & 18.1 & -8.5 & -2.1 & -9.3 & -13.1 & 77.6 \\
Taiwan & -21.7 & 1.2 & -0.5 & & -4.4 & 5.4 & 0.8 & 4.1 & 1.7 & -13.4 \\
ASEAN & 69.1 & 37.8 & 13.4 & -1.4 & 54.7 & -4.6 & -2.0 & -5.7 & -8.6 & 152.8 \\
United States & -20.3 & -8.5 & -6.1 & -0.2 & -8.7 & & 3.3 & 8.0 & 4.2 & -28.2 \\
Canada and ANZ & -5.1 & -0.9 & -0.8 & -0.2 & -1.9 & 2.4 & 0.3 & 1.1 & 0.7 & -4.5 \\
EU-15 & -17.3 & 2.0 & 0.7 & -1.6 & -6.5 & -2.4 & -0.9 & -11.4 & -1.5 & -38.9 \\
Rest of world & -22.5 & -7.1 & -0.5 & -0.8 & 1.5 & 2.5 & 0.1 & -2.0 & 0.9 & -27.9 \\
World & 200.9 & 113.3 & 75.6 & -12.8 & 146.9 & -25.7 & -3.6 & -23.0 & -22.2 & 449.3 \\
\hline
\end{tabular}

United States and a substantial deficit with East Asia would result in a transitive surplus for its regional partners. While this might be a desirable property from the East Asian perspective, it puts China in a difficult position as a member of less inclusive East Asian arrangements. This is because, to join such an arrangement, China is implicitly expected to expand exports outside the region by significantly reducing extra-regional imports. This might complicate bilateral relations, particularly with respect to the OECD countries, for a newly emergent WTO member.

Of great interest to this paper is the trilateral scenario, the trade flow results of which are given in Table 5. Here we see compositional adjustments that include substantial trade creation among the three principals, as well as significant trade diversion. While the former outweighs the latter, the incidence of trade diversion is such that we might expect vigorous challenges to emergent Trilateralism in the Asian Pacific. While trade growth is about three times the total amount of trade diversion, every country and region outside the agreement

Table 5

Effects on trade flows resulting from China-Japan-US FTA (deviations from the baseline in 2015 in US\$ billion in 1997 prices)

\begin{tabular}{|c|c|c|c|c|c|c|c|c|c|c|}
\hline \multirow[t]{2}{*}{ Exporting region } & \multicolumn{10}{|c|}{ Importing region } \\
\hline & $\begin{array}{l}\text { China } \\
\text { and HK }\end{array}$ & Japan & Korea & Taiwan & ASEAN & $\begin{array}{l}\text { United } \\
\text { States }\end{array}$ & $\begin{array}{l}\text { Canada } \\
\text { and ANZ }\end{array}$ & EU-15 & ROW & World \\
\hline China/Hong Kong & 40.0 & 65.8 & 1.0 & 0.3 & 0.5 & 138.0 & 0.9 & 7.2 & -1.9 & 252.0 \\
\hline Japan & 162.4 & & -7.1 & -8.4 & -18.6 & 62.5 & -4.3 & -21.2 & -13.5 & 151.9 \\
\hline Korea & -16.5 & -1.3 & & 0.2 & 0.5 & -3.3 & 0.6 & 2.3 & 3.2 & -14.3 \\
\hline Taiwan & -20.4 & 0.2 & 0.4 & & 1.8 & -2.0 & 0.8 & 3.6 & 1.5 & -14.1 \\
\hline ASEAN & -11.5 & -6.5 & 0.4 & 0.1 & 0.5 & -15.9 & 0.4 & 3.8 & 1.2 & -27.6 \\
\hline United States & 130.0 & 98.0 & -4.7 & -4.0 & -8.5 & & -17.3 & -26.4 & -28.7 & 138.4 \\
\hline Canada and ANZ & -6.4 & -2.2 & 0.4 & -0.1 & 0.4 & -15.2 & 0.4 & 2.0 & 1.1 & -19.7 \\
\hline EU-15 & -19.7 & -0.7 & -1.3 & -1.2 & -1.8 & -16.0 & -0.6 & -8.9 & -4.9 & -55.1 \\
\hline Rest of world & -21.4 & -8.4 & -0.4 & -0.4 & -0.1 & -21.9 & 0.6 & 2.6 & 2.6 & -46.9 \\
\hline World & 236.5 & 145.0 & -11.5 & -13.4 & -25.3 & 126.1 & -18.5 & -34.9 & -39.4 & 364.6 \\
\hline
\end{tabular}


experiences an absolute decline in aggregate exports. This strong and uniform diversion is again a result of the relatively high prior protection in China and Japan. For this reason, it is reasonable to expect mitigation of this effect over time, at least from the Chinese side, as WTO conformity levels the playing field for countries outside the trilateral agreement.

Why does Trilateralism look better to China than other regional arrangements? The answer, as suggested already, is partly market size. Another important aspect, however, is economic diversity. By joining with the United States and Japan, China gets access to more diversified import demand and export supply than is available in ASEAN and the EU. This kind of diversification reinforces international division of labor and is one of the primary attractions of North-South regionalism. ${ }^{16}$

Even with strong trade diversion, does Pacific Trilateralism provide a solid stepping stone to global free trade? To the extent that it accelerates trade between the three largest economies in the region, such an agreement can advance the case for greater global interdependence although the exclusion of agricultural liberalization would considerably reduce potential economic gains. Whether or not Trilateralism is really on the path to globalization, however, depends upon the nature of the structural adjustments ensuing from both trade regimes. A key question is whether the composition of sectoral output, factor use, and trade arising from Trilateralism are structurally consistent with patterns of comparative advantage that would emerge in the same countries under long-run WTO implementation. This question can only be answered conclusively by detailed analysis of sectoral information, the next stage of our work in progress.

For the present, an important lesson drawn from our work is that the largest economies in the region have a strong incentive to take the lead in any regional liberalization initiatives. For China, Japan, and the United States, trilateral liberalization dominates other FTAs examined in this paper. Other economies in the region, particularly the ASEAN countries, have strong incentive to enlist them in less inclusive arrangements, and they are making progress in their negotiations with China and Japan.

\section{Concluding remarks}

China's accession to the WTO portends dramatic evolution for the East Asian and Pacific economic regions. Over the last two decades, China has established new standards for sustained growth and dynamic resource allocation by a large economy, and further Chinese domestic and external liberalization will redefine trade relations in ways that are only beginning to be understood. Initial reactions of regional partners, who perceive China as a strong export competitor and magnet for FDI, have been rather defensive. These sentiments could undermine multilateralism and retard the dramatic historical progress of regional trade and growth.

In this paper, we have examined how regional trade might evolve under a variety of alternative trade regimes, including free trade among the ASEAN+3 countries and a trilateral FTA among the largest regional economies, China, Japan, and the United States.

\footnotetext{
16 The case for North-South regionalism has been strenuously argued along these lines in, among others, World Bank (2000).
} 
We have also experimented with FTA scenarios in the absence of agricultural liberalization. Our general findings indicate that China has made the right decision to move directly toward globalization, but that Trilateralism might be a convenient stepping stone in that direction, particularly if food and agricultural products are liberalized to a great extent. We find that a trilateral FTA will bring about very large fractions of the GTL's aggregate benefits to China, Japan, and the United States, although these benefits are likely to come at the expense of extra-regional bilateral relations. ${ }^{17}$

In contrast to an FTA that diverts China's trade into smaller regional markets (e.g., ASEAN-China FTA), a trilateral arrangement would provide both the market depth and diversity necessary to absorb China's burgeoning export capacity and meet its complex import needs. China's diversity and scale are also apparently sufficient to meet the needs of the Pacific giants, the United States and Japan. Thus we estimate that more efficient allocation of comparative advantage among these three economies would realize substantial gains from trade, especially when this arrangement includes agricultural liberalization. Exactly how this relationship would evolve in terms of structural adjustment, however, will not be clear until we conduct more detailed sectoral analysis. This extension of the present work is non-trivial to its policy implications because adversely affected industry lobbies are likely to strongly oppose new trade agreements. Suffice for the present to say that Trilateralism appears to offer relatively large potential gains for China, Japan, and the United States, but that this potential will be realized only if the implied sectoral and extra-FTA trade adjustments are politically feasible. As we have seen from recent actions by the United States in the steel and agricultural sectors, one cannot even take for granted the political feasibility of prior commitments to the WTO, let alone a hypothetical FTA. There may be many microeconomic obstacles to a Pacific Trilateral FTA, but the stakes do seem high enough to justify closer examination of this prospect.

\section{Acknowledgements}

The authors would like to thank Frank S.T. Hsiao, Michael G. Plummer, and Eiichi Tomiura for helpful comments and gratefully acknowledge the financial support from the Japan Foundation Center for Global Partnership.

\section{References}

Bhagwati, J. (1995). US trade policy: The infatuation with free trade areas. In J. Bhagwati \& A. O. Krueger (Eds.), The dangerous drift to preferential trade agreements. Washington, DC: American Enterprise Institute for Public Policy Research.

Brown, D. K., Deardorff, A. V., \& Stern, R. M. (1992). A North American free trade agreement: Analytic issues and a computational assessment. World Economy, 15, 15-29.

\footnotetext{
$\overline{17}$ It should be noted that the magnitudes of welfare gains reported in Section 3 are likely to be underestimated because the present version of the model does not incorporate increasing returns to scale or allow foreign capital to move in response to a change in relative rates of return.
} 
Brown, D. K., Deardorff, A. V., \& Stern, R. M. (2003). Multilateral, regional, and bilateral trade-policy options for the United States and Japan. World Economy, 26, 803-828.

Brown, D. K., \& Stern, R. M. (1989). US-Canada bilateral tariff elimination: The role of product differentiation and market structure. In F. C. Feenstra (Ed.), Trade policies for international competitiveness. Chicago: University of Chicago Press.

Dimaranan, B. V., \& McDougall, R. A. (Eds.) (2002). Global trade, assistance, and production: The GTAP 5 data base. West Lafayette: Center for Global Trade Analysis, Purdue University (http://www.gtap.agecon.purdue.edu/databases/v5/v5_doco.asp).

Drysdale, P. (2002). China, the WTO and East Asian economic diplomacy. In P. Drysdale \& K. Ishigaki (Eds.), East Asian trade and financial integration: New issues. Canberra: Asia Pacific Press.

Dutta, M. (2000). The Euro revolution and the European Union: Monetary and economic cooperation in the Asia-Pacific region. Journal of Asian Economics, 11, 65-88.

Ethier, W. (1998). The new regionalism. Economic Journal, 108, 1149-1161.

Francois, J. F., \& Roland-Holst, D. (1997). Industry structure and conduct in an applied general equilibrium context. In J. F. Francois \& K. A. Reinert (Eds.), Applied methods for trade policy analysis: A handbook. Cambridge: Cambridge University Press.

Fujita, M., Krugman, P., \& Venables, A. J. (1999). The spatial economy: Cities, regions, and international trade. Cambridge, MA: MIT Press.

Fukase, E., \& Winters, L. A. (2003). Possible dynamic effects of AFTA for the new member countries. World Economy, 26, 853-871.

Harris, R. G. (1984). Applied general equilibrium analysis of small open economies with scale economies and imperfect competition. American Economic Review, 74, 1017-1032.

Harrison, G. W., Rutherford, T. F., \& Tarr, D. G. (1996). Increased competition and completion of the market in the European Union. Journal of Economic Integration, 11, 332-365.

Helpman, E., \& Krugman, P. R. (1985). Market structure and foreign trade: Increasing returns, imperfect competition, and the international economy. Cambridge, MA: MIT Press.

Howe, H. (1975). Development of the extended linear expenditure system from simple savings assumptions. European Economic Review, 6, 305-310.

Kahler, M. (1995). International institutions and the political economy of integration. Washington, DC: Brookings Institution.

Keuschnigg, C., \& Kohler, W. (2000). Eastern enlargement to the EU: A dynamic general equilibrium perspective. In G. W. Harrison, S. E. H. Jensen, L. H. Pedersen, \& T. F. Rutherford (Eds.), Using dynamic general equilibrium models for policy analysis. Amsterdam: North-Holland.

Kreinin, M. E., \& Plummer, M. G. (1994). Structural change and regional integration in East Asia. International Economic Journal, 8(2), 1-12.

Krueger, A. O. (1999a). Are preferential trading arrangements trade-liberalizing or protectionist? Journal of Economic Perspectives, 13(4), 105-125.

Krueger, A. O. (1999b). Trade creation and trade diversion under NAFTA (NBER Working Paper No. 7429). Cambridge, MA: National Bureau of Economic Research.

Laird, S. (1999). Regional integration agreements: Dangerous liaisons? World Economy, 22, 1179-1200.

Lee, H., Roland-Holst, D., \& van der Mensbrugghe, D. (2002). Emergence of China and the implications for regional trade initiatives in the Asian Pacific (Working Paper No. 2002-27). Kitakyushu: International Center for the Study of East Asian Development (http://www.icsead.or.jp/index_e.html).

Lee, H., \& van der Mensbrugghe, D. (2001). A general equilibrium analysis of the interplay between foreign direct investment and trade adjustments (Working Paper No. 2001-18). Kitakyushu: International Center for the Study of East Asian Development (http://www.icsead.or.jp/index_e.html).

Lee, H., \& van der Mensbrugghe, D. (2004). EU enlargement and its impacts on East Asia. Journal of Asian Economics, 14(6), 843-860.

Levy, P. I. (1997). A political-economic analysis of free trade agreements. American Economic Review, 87, 506-519.

Lluch, C. (1973). The extended linear expenditure system. European Economic Review, 4, 21-32.

Madsen, A. D., \& Sorensen, M. L. (2002). Economic consequences for Denmark of EU enlargement [mimeo]. Copenhagen: Danish Rational Economic Agents Model (http://www.ecomod.net/conferences/ecomod2002/ papers/due.pdf). 
Panagariya, A. (1999). Regionalism in trade policy: Essays on preferential trading. London: World Scientific. Panagariya, A. (2000). Preferential trade liberalization: The traditional theory and new development. Journal of Economic Literature, 38, 287-331.

Petri, P. A. (1997). Foreign direct investment in a computable general equilibrium framework. Paper presented at the Brandeis-Keio conference on "Making APEC work: Economic challenges and policy alternatives," Keio University, Tokyo, March 13-14.

Robinson, S., \& Thierfelder, K. (1999). Trade liberalization and regional integration: The search for large numbers (Discussion Paper No. 34). Washington, DC: International Food Policy Research Institute.

Roland-Holst, D., Reinert, K. A., \& Shiels, C. R. (1992). North American trade liberalization and the role of nontariff barriers. In Economy-wide modelling of the economic implications of a FTA with Mexico and a NAFTA with Mexico and Canada (USITC Publication No. 2508). Washington, DC: US International Trade Commission.

Samuelson, P. A. (1952). The transfer problem and transport costs: The terms of trade when impediments are absent. Economic Journal, 62, 278-304.

Smith, A., \& Venables, A. J. (1988). Completing the internal market in the European Community: Some industry simulations. European Economic Review, 32, 1501-1525.

Srinivasan, T. N. (1998a). Developing countries and the multilateral trading system: From GATT to the Uruguay Round and the future. Boulder: Westview Press.

Srinivasan, T. N. (1998b). Regionalism and the WTO: Is nondiscrimination passé? In A. O. Krueger (Ed.), The WTO as an international organization. Chicago: University of Chicago Press.

Tran, V. H. (2003). New Asian regionalism: Evidence of ASEAN+3 free trade agreement from extended gravity theory and new modelling approach (Economics Working Paper Series 03-03). Wollongong, NSW: University of Wollongong (http://www.uow.edu.au/commerce/econ/workingpapers/WP03-03.pdf).

van der Mensbrugghe, D. (2003). Linkage technical reference document: Version 5.3. Washington, DC: The World Bank (http://www.worldbank.org/prospects/pubs/TechRef.pdf).

World Bank (2000). Trade blocs (Policy Research Report). Washington, DC: The World Bank.

Yamazawa, I., \& Hiratsuka, D. (2003). Toward ASEAN-Japan comprehensive economic partnership (IDE Development Perspective Series No. 24). Tokyo: Institute of Developing Economies.

Yeats, A. (1998). Does Mercosur's trade performsance raise concerns about the effects of regional trade arrangements? World Bank Economic Review, 12, 1-28. 